JINOTEP Vol 8 (2) (2021): 178-185

DOI: $10.17977 / \mathrm{um} 031 \mathrm{v} 8 \mathrm{i} 22021 \mathrm{p} 178$

JINOTEP (Jurnal Inovasi Teknologi Pembelajaran)

Kajian dan Riset Dalam Teknologi Pembelajaran

http://journal2.um.ac.id/index.php/jinotep/index

\title{
KAJIAN LITERATUR SISTEMATIS BLENDED LEARNING DALAM MENINGKATKAN MOTIVASI DAN HASIL BELAJAR SISWA SMK
}

Yuanita Aritantia, Supari Muslim, Theodorus Wiyanto Wibowo, Tri Rijanto, Mochamad Cholik

Program Studi S2 Pendidikan Teknologi dan Kejuruan, Universitas Negeri Surabaya - Surabaya

\begin{tabular}{l} 
Article History \\
\hline Received: 14-06-2021 \\
Accepted: 03-07-2021 \\
Published: 04-07-2021 \\
Available online: 03-07- \\
2021 \\
\hline Keywords \\
\hline $\begin{array}{l}\text { blended learning; hasil } \\
\text { belajar; media belajar; } \\
\text { motivasi belajar; student } \\
\text { performance; learning } \\
\text { media; learning } \\
\text { motivation }\end{array}$ \\
\hline
\end{tabular}

\begin{abstract}
Abstrak
Covid-19 memberikan pengaruh kepada berbagai sektor salah satunya pendidikan. Proses perubahan model pembelajaran dari face to face menjadi daring dan luring maupun kombinasi yang dapat memberikan pengaruh. Siswa mengeluhkan kurangnya interaksi bersama guru sehingga kehilangan motivasi belajar yang dapat menurunkan hasil belajar sehingga perlu alternatif pemecahan masalah tersebut. Karenanya, peneliti meneliti mengenai bagaimana penerapan model blended learning pada siswa SMK serta pengaruhnya menggunakan berbagai media $e$ learning terhadap motivasi dan hasil belajar menggunakan metode penelitian kajian literatur sistematis agar nantinya sebagai pertimbangan pelaksanaan blended learning di masa covid 19. Kesimpulannya, model blended learning menggunakan media online e learning Edmodo, LMS Moodle, maupun Google Classroom menghasilkan hasil yang sama yaitu dapat meningkatkan motivasi dan hasil belajar siswa. Namun, google classroom lebih direkomendasikan.
\end{abstract}

Abstract

Covid-19 has had an impact on various sectors, one of which is education. The process of changing the learning model from face to face to online and offline as well as a combination that can have an impact. Students complain about the lack of interaction with the teacher so that they lose motivation to learn which can reduce learning outcomes so that alternative solutions are needed. Therefore, researchers examined how the application of the blended learning model to vocational students and the effect of using various e-learning media on motivation and learning outcomes using a systematic literature review research method would be used as a consideration for the implementation of blended learning during the covid 19 period. In conclusion, the blended learning model uses media online e-learning Edmodo, LMS Moodle, and Google Classroom produced the same results, namely increasing student motivation and learning outcomes. However, Google Classroom is more recommended.

Corresponding author: Yuanita Aritantia

Adress: Jl. Jaksa Agung Suprapto II, Kediri, Jawa Timur 64112

Instansi: Universitas Negeri Surabaya

E-mail: yuanita.20012@mhs.unesa.ac.id
2021 Universitas Negeri Malang p-ISSN 2406-8780 e-ISSN 2654-7953 


\section{PENDAHULUAN}

World Health Organization (WHO) telah menetapkan wabah corona virus disease 2019 (Covid-19) sebagai pandemi pada tanggal 11 Maret 2020. Dirjen WHO, Dr Tedros Adhanom Ghebreyesus, mengatakan bahwa penetapan dilakukan berdasarkan peninjauan tingkat penyebaran dan keparahan yang mengkhawatirkan. Covid 19 telah memberikan dampak kepada berbagai sektor salah satunya pendidikan. Dalam upaya pencegahan penularan, pemerintah melalui Kementerian Pendidikan dan Kebudayaan Pemerintah telah memberikan pedoman penyelenggaraan belajar dari rumah (BDR) sebagai respon atas situasi darurat penyebaran covid 19 berdasarkan Surat Edaran Kemendikbud Dikti No. 15 tahun 2020.

Menurut pemberitahuan Kemendikbud Dikti No. 15 tahun 2020, Belajar dari rumah (BDR) dilaksanakan dengan metode pembelajaran jarak jauh (PJJ) yang terbagi dalam dua jenis pendekatan yaitu pembelajaran jarak jauh dalam jaringan yang biasa disingkat daring dan pembelajaran jarak jauh luar jaringan yang biasa disingkat luring. Daring merupakan seluruh kegiatan yang dilakukan terhubung dengan jaringan koneksi internet dan komputer sedangkan luring dapat diartikan terputus dari internet. Pada proses pelaksanaanya pembelajaran daring memerlukan dukungan berbagai jenis perangkat mobile seperti smartphone, laptop, tablet untuk dipergunakan dalam pengaksesan informasi tanpa khawatir terbatas waktu dan tempat (Gikas \& Grant, 2013). Satuan pendidikan dapat memilih pembelajaran diantara pendekatan daring, luring atau keduanya dengan penyesuaian sarana dan prasarana yang tersedia agar tidak mempengaruhi hasil belajar siswa.

Saat ini, proses pembelajaran selama masa pandemi covid-19 dilakukan dengan dua cara yaitu secara daring menggunakan beragam pilihan seperti Zoom, Google Meet, Google Classroom, WhatApp ketika pemberian materi dan secara langsung / offline / face to face dengan cara bergiliran ketika praktek produktif sesuai protokol kesehatan yang ditetapkan pemerintah. Penggunaan ke dua cara tersebut dapat juga disebut sebagai blended learning. Blended learning merupakan konsep revolusioner yang mencangkup pengajaran di kelas tradisional (classroom lesson) dan online learning (Hijazi \& AlNatour, 2020) (Keshavarz \& Hulus, 2019). Penggunaan model blended learning dengan menggunakan e-learning saat pembelajaran online yang terintegrasi dan terstruktur akan membuat proses pembelajaran berlangsung lebih bermakna (Rahman et al., 2020).

Sistem blended learning merupakan dapat diterapkan di SMK mengingat bahwa pembelajaran online secara penuh sulit untuk diterapkan. Pembelajaran tatap muka tetap diperlukan saat praktik mata pelajaran produktif, Dengan kata lain, proses pebelajaran tatap muka adalah proses penting yang tidak boleh dihilangkan meski persentasenya berkurang (Utami, 2018). Namun, penerapan blended learning perlu dikaji bagaimana penerapannya agar efektif.

Blended learning merupakan model pembelajaran dimana dalam proses pembelajarannya disediakan mode penyampaian yang beragam untuk mengoptimalkan hasil belajar siswa dan biaya penyelenggaraan program sekolah (Shamsuddin \& Kaur, 2020). Blended Learning dihasilkan dari kombinasi efektif dari berbagai cara penyampaian materi, model pembelajaran, dan gaya belajar siswa yang dilakukan secara interaktif untuk menciptaka lingkungan belajar bermakna (Kaur, 2013). Sehingga dapat disimpulkan dari berbagai pendapat bahwa blended learning merupakan perpaduan efektif dari pembelajaran face to face dan pembelajaran online dapat mengoptimalkan hasil belajar siswa.

Proses perubahan model pembelajaran dari face to face menjadi daring, luring maupun kombinasi dari keduanya dikarenakan adanya pandemi Covid 19 tentunya memberikan pengaruh terhadap motivasi maupun hasil belajar siswa. Siswa mengeluhkan kurangnya interaksi bersama guru selama pembelajaran di masa pandemi covid-19 terhadap siswa menyebabkan siswa mengalami kebosanan, stress, sehingga kehilangan motivasi belajar yang akhirnya dapat menurunkan hasil belajar. Ketika proses pembelajaran daring, banyak siswa yang siswa mengeluhkan tentang frekuensi tugas tinggi dalam jangka waktu pengumpulan terlalu singkat, kesulitan pembagian sistem kerja kelompok sampai di titik stres dalam pemilihan tugas mana yang harus diprioritaskan terlebih dahulu. Hal ini sejalan dengan (Sudjana, 2010) yang menyatakan bahwa hasil belajar siswa di sekolah dipengaruhi faktor kemampuan yang dimiliki, motivasi belajar, sosial ekonomi, ketekunan, faktor fisik dan psikis. 
180 JINOTEP (Jurnal Inovasi dan Teknologi Pembelajaran) Kajian dan Riset dalam Teknologi Pembelajaran Vol.8, No.2, Juli 2021, Hal. 178-185

\begin{abstract}
Kata motivasi berarti bergerak (move) berdasarkan bahasa latin disebut movere (Schunk et al., 2014). Motivasi memiliki pengaruh penting dalam mendasari berbagai tindakan dan perilaku siswa yang menjadi latar belakang dalam kondisi dan situasi tertentu dan dijalankan untuk mencapai tujuan tertentu (Rafiola et al., 2020). Adanya motivasi akan memberikan dorongan pada siswa sehinggga arah belajarnya dapat diketahui (Emda, 2018).

Motivasi belajar merupakan suatu keyakinan yang dipercaya oleh individu tentang kemampuannya untuk belajar, nilai-nilai yang berkaitan dengan suatu aktivitas,dan tingkat minat mereka dalam kegiatan belajar (Keshavarz \& Hulus, 2019). Secara umum, siswa termotivasi lebih bertekad untuk berprestasi dan mempertahankannya (Rahman et al., 2020). Oleh karena itu, sebuah prestasi luar biasa akan didapatkan setinggi-tingginya oleh siswa termotivasi dibandingkan dengan siswa yang tidak memiliki motivasi (Osman \& Hamzah, 2020). Oleh karena itu motivasi belajar merupakan pengaruh yang paling penting dalam hasil belajar siswa.

Hasil belajar adalah output dari proses

face) tidak sepenuhnya digantikan dengan daring (online) sehingga siswa masih dapat berinteraksi langsung bersama guru.

$$
\text { Pada penelitian sebelumnya, }
$$
menyatakan bahwa model blended learning dapat meningkatkan hasil belajar (Sihabudin, 2018). Blended learning dapat meningkatkan daya tarik, efektifitas, dan efisiensi dalam pembelajaran (Siyamta, 2017). Model blended learning berpengaruh signifikan terhadap peningkatan motivasi dan prestasi siswa (Islam et al., 2018) Hal ini diperkuat dengan penelitian yang menyatakan penggunaan model blended learning meningkatkan motivasi dan prestasi belajar (Syarif, 2013).

Oleh sebab itu, peneliti tertarik meneliti mengenai pengaruh model blended learning terhadap motivasi dan hasil belajar siswa dengan tujuan untuk mengetahui (1) bagaimana penerapan model blended learning yang terjadi pada siswa SMK (2) bagaimana pengaruh model blended learning menggunakan berbagai media e-learning terhadap motivasi belajar dan hasil belajar agar nantinya dapat digunakan sebagai solusi untuk pembelajaran selama masa pandemi covid 19.
\end{abstract} belajar untuk memperlihatkan kemampuankemampuan yang dimiliki oleh siswa setelah menerima pengalaman belajarnya (Rizkiyah, 2013). Hasil belajar dapat diketahui melalui evaluasi hasil belajar. Hasil belajar merupakan hasil dari proses belajar yang menunjukkan perubahan pengetahuan dan ketrampilan, siswa dibanding sebelumnya. Oleh karena itu, diperlukan proses evaluasi untuk mengukur sejauh mana perubahan atau penguasaan kompetensi dari peserta didik.

Blended learning bersifat serbaguna, bergantung kepada keputusan instruktur ketika harus memilih dari berbagai pilihan penggunaan teknologi, tergantung pada konteks pembelajaran. Blended learning dapat membantu meningkatkan efikasi diri akademik dan motivasi siswa (Rafiola et al., 2020). Blended learning merupakan pendekatan yang terbaik dalam menggabungkan pembelajaran sinkronus (pembelajaran guru dan siswa dilakukan bersamaan menggunakan bantuan teknologi) dan asinkronus (guru menyiapkan materi terlebih dahulu, dan interaksi pembelajaran dilakukan lebih fleksibel) (Maarop \& Embi, 2016). Oleh karena itu, model blended learning dapat diterapkan selama masa pandemi covid-19 agar unsur pembelajaran luring (face to

\section{METODE}

Metode penelitian yang digunakan adalah sistematik literatur review, adalah penggunaan metodologi yang sistematis dan eksplisit untuk mengidentifikasi, memilih, dan mengevaluasi secara kritis hasil studi dalam peninjauan yang terencana dengan baik untuk menjawab pertanyaan penelitian tertentu (Rother, 2007). Pencarian dilakukan dilakukan menggunakan Eric, Google Scholar, dan Science Direct menggunakan Bahasa Indonesia dan Bahasa Inggris pada tahun 2011 - 2021 sesuai sub-bab kriteria pemilihan dan penolakan.

\section{Kriteria Pemilihan dan Penolakan Artikel}

Kriteria pemilihan artikel mengikuti alur pada Gambar 1. Pencarian pertama penggunaan blended learning dalam pembelajaran dengan filter tahun 2011-2021 agar kajian yang dilakukan masih relevan untuk digunakan. Selanjutnya dipersempit dengan pengaruh blended learning terhadap kriteria motivasi belajar dan hasil belajar. Kemudian media yang digunakan dibatasi Edmodo, LMS Moodle, dan Google Classroom. Ketiga media belajar ini merupakan media yang sering muncul dalam pencarian blended learning dan yang terakhir siswa yang menjadi sampel dalam jurnal dipilih 
siswa SMK. Kriteria penolakan artikel adalah blended learning yang dilaksanakan pada tingkat di bawah SMK seperti SD dan SMP, rentang tahun diluar 2011-2021, ketidaksesuaian kata kunci pencarian yang muncul dengan keseluruhan isi jurnal. Uraian kriteria pemilihan lebih lengkap ditampilkan pada Gambar 1, Tabel 1, dan Tabel 2.

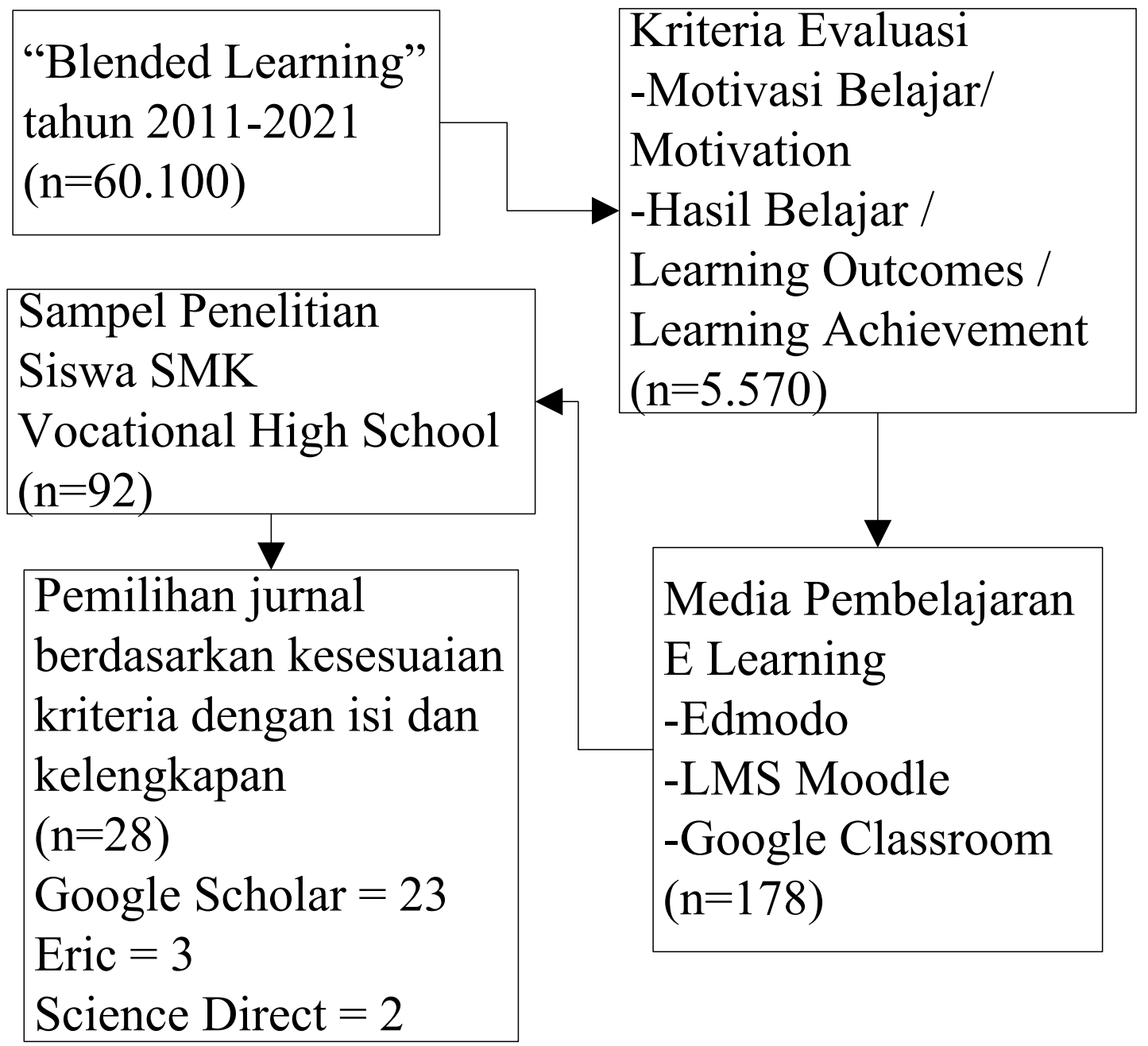

Tabel 1. Jumlah Artikel Berdasarkan Tahun

Gambar 1. Alur pemilihan artikel untuk dikaji

\begin{tabular}{|c|c|c|}
\hline \multicolumn{3}{|c|}{ dan Negara } \\
\hline Tahun & Jumlah & Negara \\
\hline \multirow[t]{3}{*}{2013} & 6 & Indonesia $(n=4)$ \\
\hline & & USA $(n=1)$ \\
\hline & & India $(n=1$ \\
\hline 2014 & 1 & Turki \\
\hline 2015 & 2 & Indonesia \\
\hline \multirow[t]{2}{*}{2016} & 2 & Kanada (n=1) \\
\hline & & Indonesia $(\mathrm{n}=1)$ \\
\hline \multirow[t]{2}{*}{2017} & 2 & Indonesia $(n=1)$ \\
\hline & & USA $(n=1)$ \\
\hline \multirow[t]{2}{*}{2018} & 4 & Indonesia $(n=3)$ \\
\hline & & $\mathrm{UK}(\mathrm{n}=1)$ \\
\hline \multirow[t]{2}{*}{2019} & 2 & Indonesia $(n=1)$ \\
\hline & & Australia $(\mathrm{n}=1)$ \\
\hline \multirow[t]{4}{*}{2020} & 9 & Indonesia $(\mathrm{n}=5)$ \\
\hline & & Austria $(n=1)$ \\
\hline & & India $(n=1)$ \\
\hline & & USA $(n=2)$ \\
\hline
\end{tabular}

Tabel 2. Jumlah Jurnal Berdasarkan Kriteria

\begin{tabular}{lcc}
\hline \multicolumn{1}{c}{ Kriteria } & Jumlah & Persentase \\
\hline Blended learning & 28 & $100 \%$ \\
Motivasi / & 12 & $42,86 \%$ \\
$\begin{array}{l}\text { Motivation } \\
\text { Hasil Belajar/ }\end{array}$ & 15 & $53,57 \%$ \\
$\begin{array}{l}\text { Learning Outcomes / } \\
\text { Learning } \\
\text { Achievement } \\
\text { Media E Learning: }\end{array}$ & 16 & $57,14 \%$ \\
-Edmodo \\
-LMS Moodle
\end{tabular}


182 JINOTEP (Jurnal Inovasi dan Teknologi Pembelajaran) Kajian dan Riset dalam Teknologi Pembelajaran Vol.8, No.2, Juli 2021, Hal. 178-185

\section{HASIL DAN PEMBAHASAN}

Berdasarkan metode penelitian sistematik literatur review dari berbagai jurnal yang berhubungan dengan pengaruh model blended learning pada siswa SMK, maka didapatkan hasil sebagai berikut:

Penerapan model blended learning menggunakan media online Edmodo pada siswa konstruksi Rangka Pesawat Udara SMKN 12 Bandung. Jenis penelitian menggunakan desain quasi experimental. Instrument penelitian menggunakan tes praktik menggambar dan observasi. Hasil penelitian menujukkan nilai normalized-gain sebesar 0,75 berada dalam kategori tinggi sehingga dapat dikatakan pembelajaran dengan model blended learning pada materi menggambar 2 dimensi menggunakan CAD dapat meningkatkan hasil belajar (Priono et al., 2019).

Hal ini didukung penelitian pada siswa SMKN 2 Purwodadi yang menyatakan pengembangan video simulasi dan kelas maya media dalam blended learning menggunakan Edmodo bersifat praktis ditinjau dari respon pengguna terhadap fitur sistem Edmodo. Sehingga, Edmodo dapat membantu mempermudah peserta didik dalam kegiatan pembelajaran (Kurniawati \& Djuniadi, 2015).

Penerapan model blended learning menggunakan media LMS Moodle pada siswa teknik gambar bangunan SMKN 7 Surabaya. Jenis penelitian tindakan kelas. Instrument penelitian menggunakan lembar tes, lembar observasi kegiatan, dan lembar angket respon siswa. Hasil pretest menunjukkan presentase ketuntasan belajar sebesar 30,30\%. Peningkatan hasil belajar terjadi pada setiap siklus. Pada siklus 1 menjadi $72,73 \%$ dan siklus 2 menjadi $87,78 \%$. Hal ini menujukkan terjadi peningkatan ketuntasan belajar yang artinya hasil belajar meningkat. Respon siswa dalam penerapan blended learning dalam kategori sangat baik yang artinya siswa merasa pembelajaran dengan blended learning menciptakan suasana kelas menyenangkan sehingga memotivasi siswa untuk belajar (Rizkiyah, 2013).

Penerapan model blended learning menggunakan media e learning berupa LMS Moodle pada siswa SMK Muhammadiyah 3 Yogyakarta bidang teknik pemesinan. Jenis penelitian yang diterapkan adalah desain quasi experimental. Instrument penelitian menggunakan dokumentasi dan tes pilihan ganda. Hasil penelitian menujukkan peningkatan signifikan terhadap prestasi belajar siswa dengan nilai $\mathrm{t}$ hitung $16,60>\mathrm{t}$ tabel $=2,002$ setelah diterapkannya blended learning (Achmadi, 2015).

Hal ini sejalan dengan penelitian pada siswa SMK Muhammadiyah 1 Klaten yang menyatakan media blended learning berbasis Moodle LMS (Learning Management System) cocok diterapkan dan efektif digunakan untuk meningkatkan pemahaman materi dan hasil belajar siswa karena berisi fitur pengumuman, referensi buku bacaan, tanya jawab dengan guru, materi (teks, audio, video), ujian, diskusi, tugas yang dapat membantu proses pembelajaran (Setiawan et al., 2020).

Hal ini didukung penelitian pada siswa SMKN 1 Satui menggunakan media LMS. Jenis penelitian desain quasi experimental. Instrument penelitian menggunakan soal tes tertulis dan angket. Hasil penelitian menujukkan peningkatan motivasi belajar setelah diterapkannnya dengan nilai rata-rata sebesar 13,55 dan hasil belajar rata-rata sebesar 38,23 (Sjukur, 2013). Pada penelitian didapat nilai tratio $=6.468$ lebih tinggi dibandingkan dengan $\mathrm{t}$ table $=2.056$.yang artinya blended learning dengan LMS Moodle menambah motivasi para siswa karena memberikan banyak kesempatan untuk mengeksplorasi kebutuhan dan potensi siswa, serta keleluasaan tempat dan waktu untuk belajar (Syafii et al., 2016).

Penerapan model blended learning menggunakan media $e$ learning berupa google classroom pada siswa bisnis konstruksi dan properti SMKN 1 Palangkaraya. Jenis penelitian yang digunakan desain quasi experimental. Instrument penelitian menggunakan tes pilihan ganda dan angket. Hasil angket respon siswa diperoleh rata-ratal skor sebesar $76,27 \%$ dan masuk dalam kategori sangat kuat. Hasil penelitian menujukkan pengaruh signifikan terhadap peningkatan hasil balajar siswa dimana ketuntasan belajar siswa mampu mencapai 100\% pada tahap proses pembelajaran (Kristina et al., 2020).

Penerapan model blended learning menggunakan media $e$ learning berupa google classroom pada siswa SMK Mabdaul Ma'arif Jember bidang TKJ. Jenis penelitian yang digunakan desain quasi experimental. Instrument penelitian menggunakan tes uraian dan kuisioner. Hasil penelitian menunjukkan nilai sig $0,038<0,05$, kemudian nilai t hitung $>$ 
t tabel $(2,156>1,688)$ yang artinya terdapat kenaikan motivasi dan hasil belajar siswa setelah diterapkannya blended learning (Rofiqoh et al., 2020). Pengajar dapat membuat kelas maya, mendistribusikan materi dan tugas, memberikan skor, mengirim saran, dan melihat semua kegiatan di satu tempat pada google classroom (Kristina et al., 2020). Google classroom memiliki kelebihan karena setiap siswa biasanya telah memiliki akun gmail yang memudahkan untuk sign in. Kemudian terdapat fitur google meet yang dapat digunakan untuk melakukan sesi meeting online. Pada sesi meeting online siswa dapat berinteraksi dengan guru maupun teman sekelas seperti berada didalam kelas pembelajaran tatap muka di sekolah.

Berdasarkan berbagai review jurnal diatas, Penerapan model blended learning adalah solusi tepat untuk menjawab tantangan dunia pendidikan di tengah pandemi covid 19 pada pembelajaran di SMK. Siswa yang telah melalui proses pembelajaran blended learning lebih berhasil dibandingkan menggunakan pembelajaran tradisional (Kazu \& Demirkol, 2014). Model blended learning dapat memenuhi presentase pembelajaran terdiri dari $70 \%$ praktik dengan face to face dan 30\% teori menggunakan media online seperti pada jurnal yang direview sebelumnya yaitu media e learning Edmodo, Moodle LMS, dan Google Classroom. Hal ini sesuai dengan pernyataan bahwa pembelajaran dapat dikatakan efektif apabila dapat menggunakan teknologi informasi dan komunikasi secara optimal dalam proses pembelajarannya sebagai alat bantu (Hanum, 2013).

Manfaat media pembelajaran membantu interaksi selama kegiatan pembelajaran antara guru dengan siswa agar lebih efektif dan efisien (Hanum, 2013). Penggunaan blended learning dengan paduan metode face to face dan berbagai media online e learning diharapkan mampu menciptakan keefektifan sehingga mampu meningkatkan motivasi belajar dan hasil belajar karena siswa tidak akan kehilangan interaksi bersama guru. Pada penelitian menjelaskan jika ingin meningkatkan motivasi peserta didik, maka bahan ajar dan metode pembelajaran harus disesuaikan dengan kebutuhan (Keshavarz \& Hulus, 2019).

Keefektifan dalam penggunaan model Blended learning mempengaruhi motivasi belajar siswa secara signifikan karena sistem pembelajarannya lebih fleksibel dan siswa merasa terbantu dengan adanya internet.
Lingkungan e learning pada Blended learning yang sukses terdiri dari (1) pertemuan awal face to face, (2) tugas online dan konsultasi lewat email setiap minggu, (3) saat akhir ditutup ujian tulis dengan face to face atau ujuan tulis di kelas dengan bantuan pengawas. (Kholifah et al., 2020). Secara keseluruhan, persyaratan untuk mendapatkan kesuksesan dalam penerapan model blended learning adalah (1) guru yang terlatih dengan baik, (2) guru yang memiliki sikap ilmiah, (3) guru yang berpandangan luas dan berpikiran positif, (4) fasilitas yang lengkap, (5) siswa memiliki akses internet pribadi, (6) fleksibilitas dalam sistem, (7) kesadaran dan persetujuan orang tua, dan (8) Evaluasi dan penilaian yang berkelanjutan (Lalima \& Lata Dangwal, 2017). Blended learning tetap membutuhkan peran guru dan orang tua siswa dalam mendampingi dan mengevaluasi selama pembelajaran berlangsung.

\section{SIMPULAN}

Berdasarkan hasil penelitian dari studi literatur yang dilakukan, model blended learning dapat memberikan peningkatkan terhadap motivasi belajar dan hasil belajar. Ketika motivasi belajar meningkat maka siswa dengan senang dan tanpa ada paksaan akan belajar yang mengakibatkan hasil belajar ikut meningkat. Penggunaan media online e learning Edmodo, LMS Moodle, Google Classroom ketika pelaksanaan model blended learning menghasilkan hasil yang sama yaitu peningkatan rata-rata hasil belajar dan motivasi belajar siswa. Namun, Google classroom memiliki kelebihan karena setiap siswa biasanya telah memiliki akun gmail yang memudahkan untuk sign in. Kemudian terdapat fitur google meet yang dapat digunakan untuk melakukan sesi meeting online. Format yang digunakan untuk di upload ke dalam suatu e learning sebaiknya terdiri dari file presentasi power point, file audio, file video presentasi sehingga pembelajaran tidak monoton karena mengaktifkan indera penglihatan maupun pendengaran. Selain itu, pemberian tugas pelaksanaan diskusi dan ujian sebagai evaluasi harus tetap dilaksanakan karena penerapan blended learning bukan sekedar penggunaan media pembelajaran e learning tetapi harus diikuti dengan pendampingan dan evaluasi terhadap siswa meski dilakukan secara online.

Meski demikian, penerapan blended learning dapat terhambat karena terkendala kesiapan sarana dan prasarana. seperti sinyal jaringan internet yang buruk, jumlah kuota 
184 JINOTEP (Jurnal Inovasi dan Teknologi Pembelajaran) Kajian dan Riset dalam Teknologi Pembelajaran Vol.8, No.2, Juli 2021, Hal. 178-185

internet dari pemerintah yang terbatas, tingkat kesiapan siswa untuk menerima peralihan model belajar baru. Hal tersebut tentunya dapat mengganggu jalannya proses pembelajaran sehingga harus diminimalisir. Siswa dapat diberikan pengarahan untuk mengelola kuota internetnya agar digunakan secara maksimal untuk kegiatan belajar seperti untuk mengakses e-book maupun materi pembelajaran untuk mengikuti perkembangan pembelajaran. Sekolah dapat menyediakan model blended learning menggunakan media online e learning yang tidak menguras banyak kuota internet namun tetap menarik serta interaktif. Sekolah juga dapat meningkatkan sarana dan prasarana untuk membuat kegiatan pembelajaran berjalan lancar sehingga dapat meningkatkan motivasi dan hasil belajar siswa. Sekolah juga harus memastikan kesiapan siswa dalam menghadapi peralihan model pembelajaran yang terjadi. Saran untuk penelitian ke depannya untuk mempertimbangkan faktor kesiapan siswa dan sikap kemandirian dalam menghadapi pembelajaran blended online.

\section{UCAPAN TERIMA KASIH}

Peneliti mengucapkan terima kasih kepada pihak Universitas Negeri Surabaya, editor jurnal, dan teman-teman S2 jurusan Pendidikan Teknologi dan Kejuruan yang telah memberikan sarana, prasarana, bimbingan ilmu dan dukungan sehingga penulis dapat menyelesaikan artikel ini.

\section{DAFTAR RUJUKAN}

Achmadi, T. A. (2015). Pengaruh Penerapan Blended Learning Terhadap Prestasi Belajar Siswa Kelas Xi Jurusan Teknik Pemesinan. Jurnal Pendidikan Teknik Mesin, 3(15), 295-302. http://journal.student.uny.ac.id/ojs/ojs/ojs/inde x.php/mesin/article/view/3294/2990

Daryanto. (2009). Panduan Proses Pembelajaran Kreatif \& Inovatif. Jakarta: AV Publisher.

Emda, A. (2018). Kedudukan Motivasi Belajar Siswa Dalam Pembelajaran. Lantanida Journal, 5(2), 172. https://doi.org/10.22373/lj.v5i2.2838

Gikas, J., \& Grant, M. M. (2013). Mobile computing devices in higher education: Student perspectives on learning with cellphones, smartphones \& social media. Internet and Higher Education, 19, 18-26. https://doi.org/10.1016/j.iheduc.2013.06.002

Hanum, N. S. (2013). Keefetifan e-learning sebagai media pembelajaran (studi evaluasi model pembelajaran e-learning SMK Telkom Sandhy
Putra Purwokerto). Jurnal Pendidikan Vokasi, 3(1), 90-102. https://doi.org/10.21831/jpv.v3i1.1584

Hijazi, D. A., \& AlNatour, A. S. (2020). The effect of using blended learning method on students' achievement in english and their motivation towards learning it: Blended learning, achievement, and motivation. International Journal of Virtual and Personal Learning Environments, 10(2), 83-96. https://doi.org/10.4018/IJVPLE.2020070106

Islam, S., Baharun, H., Muali, C., Ghufron, M. I., Bali, M. E. I., Wijaya, M., \& Marzuki, I. (2018). To Boost Students' Motivation and Achievement through Blended Learning. Journal of Physics: Conference Series, 1114(1). https://doi.org/10.1088/17426596/1114/1/012046

Kaur, M. (2013). Blended Learning - Its Challenges and Future. Procedia - Social and Behavioral Sciences, 93, 612-617. https://doi.org/10.1016/j.sbspro.2013.09.248

Kazu, I. Y., \& Demirkol, M. (2014). Effect of Blended Learning Environment Model on High School Students' Academic Achievement. Turkish Online Journal of Educational Technology - TOJET, 13(1), 78-87. https://files.eric.ed.gov/fulltext/EJ1018177.pdf

Keshavarz, M. H., \& Hulus, A. (2019). The Effect of Students' Personality and Learning Styles on Their Motivation for Using Blended Learning. Advances in Language and Literary Studies, $10(6)$, 78. https://doi.org/10.7575/aiac.alls.v.10n.6p.78

Kholifah, N., Sudira, P., Rachmadtullah, R., Nurtanto, M., \& Suyitno, S. (2020). The effectiveness of using blended learning models against vocational education student learning motivation. International Journal of Advanced Trends in Computer Science and Engineering, 9(5), 7964-7968. https://doi.org/10.30534/ijatcse/2020/1519520 20

Kristina, E., Pandiangan, P., \& Layang, S. (2020). Application Of Google Classroom Based Blended Learning Model In Creative Product and Entreprenueurship Learning Subjects In SMK Negeri Penerapan Model Blended Learning Berbasis Google Classroom Pada Mata Pelajaran Produk Kreatif dan Kewirausahaan di SMK N. 8(2), 81-85. https://ejournal.upr.ac.id/index.php/JBL/article/view/2 008/1781

Kurniawati, R., \& Djuniadi. (2015). Pengembangan Media Blended Learning Berbasis Edmodo di Sekolah Menengah Kejuruan. Indonesian Journal of Curriculum and Educational Technology Studies, 3(2), 16-24. 
https://doi.org/10.15294/ijcets.v3i2.10924

Lalima, D., \& Lata Dangwal, K. (2017). Blended Learning: An Innovative Approach. Universal Journal of Educational Research, 5(1), 129136. https://doi.org/10.13189/ujer.2017.050116

Maarop, A. H., \& Embi, M. A. (2016). Implementation of Blended Learning in Higher Learning Institutions: A Review of Literature. International Education Studies, 9(3), 41. https://doi.org/10.5539/ies.v9n3p41

Osman, N., \& Hamzah, M. I. (2020). Impact of implementing blended learning on students' interest and motivation. Universal Journal of Educational Research, 8(4), 1483-1490. https://doi.org/10.13189/ujer.2020.080442

Priono, A. I., Purnawan, P., \& Komaro, M. (2019). Pengaruh Penerapan Model Pembelajaran Blended Learning Terhadap Hasil Belajar Menggambar 2 Dimensi Menggunakan Computer Aided Design. Journal of Mechanical Engineering Education, 5(2), 129. https://doi.org/10.17509/jmee.v5i2.15179

Rafiola, R. H., Setyosari, P., Radjah, C. L., \& Ramli, M. (2020). The effect of learning motivation, self-efficacy, and blended learning on students' achievement in the industrial revolution 4.0. International Journal of Emerging Technologies in Learning, 15(8), 71-82. https://doi.org/10.3991/ijet.v15i08.12525

Rahman, Z., Rijanto, T., \& Sumbawati, M. S. (2020). the Implementation of Blended Learning Model Based on Edmodo To Improve Students' Learning Motivation and Achievement. Jurnal Pendidikan Akuntansi Indonesia, 2(9), $767-$ 775. https://doi.org/10.21831/jpai.v14i1.11371

Rizkiyah, A. (2013). Penerapan Blended Learning untuk Meningkatkan Hasil Belajar Siswa pada Mata Pelajaran Ilmu Bangunan di Kelas X TGB SMK Negeri 7 Surabaya. Jurnal Kajian Pendidikan Teknik Bangunan, 1(1), 40-49. https://jurnalmahasiswa.unesa.ac.id/index.php/ jurnal-kajian-ptb/article/view/10264/10031

Rofiqoh, J., Sucipto, T. L. A., \& Basori, B. (2020). Pengaruh Blended Learning Menggunakan Think Pair Share Berbantuan Google Classroom Dengan Traditional Learning Terhadap Hasil Belajar Dan Motivasi Belajar Siswa. Jurnal Ilmiah Pendidikan Teknik Dan Kejuruan, 13(1), 11. https://doi.org/10.20961/jiptek.v13i1.22368

Rother, E. T. (2007). Systematic literature review X narrative review. ACTA Paulista de Enfermagem, 20(2), 7-8. https://doi.org/10.1590/s010321002007000200001

Schunk, D., Meece, J., \& Pintrich, P. (2014).
Motivation in Education Theory, Research and Applications. In England: Pearson Education Limited (Fourth Edi).

Setiawan, A., Putra, D. R., Sujalwo, S., \& Cahyo, A. N. (2020). Development of Moodle-based Learning Media using Blended Learning Methods in Graphic Design Subject. IJID (International Journal on Informatics for Development), $\quad 8(2), \quad 52$. https://doi.org/10.14421/ijid.2019.08201

Shamsuddin, N., \& Kaur, J. (2020). Students' learning style and its effect on blended learning, does it matter? International Journal of Evaluation and Research in Education, 9(1), 195-202.

https://doi.org/10.11591/ijere.v9i1.20422

Sihabudin. (2018). Pengaruh Strategi Blended Learning Terhadap Hasil Belajar Mata Kuliah Sejarah Pendidikan Islam Pada Mahasiswa Yang Memiliki Locus of Control Berbeda. JINOTEP (Jurnal Inovasi Dan Teknologi Pembelajaran) Kajian Dan Riset Dalam Teknologi Pembelajaran, 3(1), 72-89. https://doi.org/10.17977/um031v3i12016p072

Siyamta. (2017). Strategi Blended Learning Flex Model Pada Pembelajaran Administrasi Jaringan Komputer Untuk Meningkatkan Pengalaman Belajar. JINOTEP (Jurnal Inovasi Dan Teknologi Pembelajaran) Kajian Dan Riset Dalam Teknologi Pembelajaran, 3(2), 122-130.

http://journal2.um.ac.id/index.php/jinotep/artic le/view/2379/1431

Sjukur, S. B. (2013). Pengaruh blended learning terhadap motivasi belajar dan hasil belajar siswa di tingkat SMK. Jurnal Pendidikan Vokasi, 2(3), 368-378. https://doi.org/10.21831/jpv.v2i3.1043

Sudjana, Nana. (2010). Dasar-Dasar Proses Belajar Mengajar. Bandung: Sinar Baru Algensindo.

Syafii, A., Raja, P., \& Ari, N. (2016). Blended Learning to Enhance Students' Motivation in Vocational School. Unila Journal English Teaching, 5(2), 1-11. http://jurnal.fkip.unila.ac.id/index.php/123/arti cle/view/11571/8236

Syarif, I. (2013). Pengaruh model blended learning terhadap motivasi dan prestasi belajar siswa SMK. Jurnal Pendidikan Vokasi, 2(2), 234249. https://doi.org/10.21831/jpv.v2i2.1034

Utami, I. S. (2018). The Effectiveness of Blended Learning as an Instructional Model in Vocational High School. Journal of Educational Science and Technology (EST), 4(1),

74. 